Vol.46, n. 4 : pp. 595-600, December 2003 ISSN 1516-8913 Printed in Brazil
BRAZILIAN ARCHIVES OF BIOLOGY AND TECHNOLOGY

AN INTERNATIONAL JOURNAL

\title{
Effect of Salt on Color and Warmed over Flavor in Charqui Meat Processing
}

\author{
Elza Y. Youssef ${ }^{1,2^{*}}$, Carlos E. Rocha Garcia ${ }^{2}$ and Massami Shimokomaki ${ }^{1,2}$ \\ ${ }^{1}$ Department of Food and Drugs Technology; Agricultural Sciences Center; State University of Londrina; \\ youssef@dilk.com.br; C. P. 6001; 86051-970; Londrina - PR - Brazil. ${ }^{2}$ Graduation Program in Food Science; \\ Department of Food Science and Experimental Nutrition; Faculty of Pharmaceutical Sciences; São Paulo \\ University; Av. Prof. Lineu Prestes, 580; 05508-900; São Paulo - SP - Brazil
}

\begin{abstract}
A combination of salt $(\mathrm{NaCl})$ high concentration and curing salt was investigated for their role in warmed-over flavor (WOF) and color changes during charqui meats processing. WOF was measured by TBARS method in uncured charqui meat $(\mathrm{CH})$ and in cured charqui known in Brazil as Jerked beef (JB). WOF occurred substantially in $\mathrm{CH}$ and sodium nitrite was able to inhibit $40-45 \%(p<0.05)$ in JB samples stored for 30 days. Color parameters also changed as evaluated by CIELAB system. The $a * / b *$ ratio showed that $C H$ samples presented brown color indicating the formation of metmyoglobin $\left(\mathrm{Fe}^{3+}\right)$ whilst JB samples presented deep red color an indication of nitrosylmyoglobin $\left(\mathrm{Fe}^{2+}\right)$ formation. Under cooking, $a * / b *$ ratio indicated the presence of denatured metmyoglobin $\left(\mathrm{Fe}^{3+}\right)$ in $\mathrm{CH}$ and formation of nitrosylmyochromogen $\left(\mathrm{Fe}^{2+}\right)$ in JB samples. The actual iron state influenced the color of charqui meat and apparently nitrite was able to chelate Fe ions, thus inhibiting development of WOF.
\end{abstract}

Key words: Intermediate moisture meat product, jerky meat, charqui meat, cured meat, rancidity, warmed over flavor inhibition

\section{INTRODUCTION}

Charqui meats are typical Brazilian intermediate moisture meat products comprising of traditional charqui meat $(\mathrm{CH})$ and of jerked beef $(\mathrm{JB})$. They are the results of application of the so-called hurdle technology in their processing and as described, salt, sodium nitrite, dehydration and packaging are hurdles sequentially applied to inhibit deteriorating microorganisms (Leistner, 1987, Shimokomaki et al., 1998). According to Brazilian legislation $\mathrm{CH}$ should contain $40-50 \%$ moisture and 10-20\% salt (Brasil, 1967) and 0.75 the final value of its aw (Torres et al., 1994, Shimokomaki et al., 1998). On the other hand,
JB is officially characterized by Brazilian legislation by having maximum moisture $55 \%$, sodium nitrite $50 \mathrm{ppm}$, salt concentration of $18 \%$, final aw value of 0.78 and should be vacuum packed (Brasil, 2000).

Color of meat is dictated by the interconversion of three pigment forms: desoxymioglobin $(\mathrm{Mb})$, which presents iron under $\mathrm{Fe}^{2+}$ state, oxymyoglobin $\left(\mathrm{MbO}_{2}\right)$ with $\mathrm{Fe}^{2+}$ and metmyoglobin (MMb) with $\mathrm{Fe}^{3+}$ (Pegg and Shahidi, 1997) and the actual iron state has not been studied in charqui meats. In addition, we have demonstrated previously that $\mathrm{NaCl}$ was able to promote lipid meat oxidation (Torres et al., 1988) and in a more pronounced way in $\mathrm{CH}$

\footnotetext{
* Author for correspondence
} 
(Torres et al. 1989). It is known that sodium nitrite has the strong property to act as antioxidant in cured meat (Younathan and Watts, 1959, Younathan, 1985, Shahidi, 1994). The term WOF was first introduced by Tims and Watts (1958) to describe the rapid development of oxidized flavor in refrigerated cooked meat upon subsequent heating. In order to understand sodium nitrite role in high salted concentrated meat product we carry out this work to study not only the color changes related to the iron state but also their consequence on the development of rancidity and warmed-over flavor during charqui and jerked beef processing.

\section{MATERIALS AND METHODS}

\section{Sample preparation}

Six beef samples weighing approximately $4.0 \mathrm{~kg}$ of Vastus lateralis m. from zebu breed aged 4-5 years old were used. The processing of $\mathrm{CH}$ and JB was carried out in a local industry and followed closely as possible the described techniques reported elsewhere (Shimokomaki et al., 1998). Meat samples were consecutively salted in $20 \%$ brine for approximately $10 \mathrm{~h}$ followed by the rock salting and drying in the sun until the moisture reached the constant value of approximately $45 \%$ and aw of $0.70-0.75$. The difference for JB processing was the curing salt introduction at a concentration of $200 \mathrm{ppm}$ in the brine and finally the ready product was vacuum packed before marketing (Shimokomaki et. al., 1998).

\section{Basic Chemical Composition}

Moisture, ash, protein, lipid were determined according to AOAC (1995). aw determination was carried out with Aqualab equipment model CX-2, USA.

\section{Lipid oxidation and WOF evaluation}

Lipid oxidation was monitored based on Tarladgis method (Tarladgis et al., 1964), and WOF was determined according to Igene and Pearson (1979). $\mathrm{CH}$ and JB samples of 30 days of storage were selected for WOF studies. Samples were exhaustively desalted with distilled water in a cold room and vacuum packed and cooked in water bath at $85^{\circ} \mathrm{C}$ until the value of $75-78^{\circ} \mathrm{C}$ of internal temperature was reached as monitored by Hanna HI 8313 thermopar. Samples were stored at $4^{\circ} \mathrm{C}$ for $48 \mathrm{~h}$ under fluorescent light (400 Lux).

\section{Color measurement}

A Hitachi U-3410 Spectrophotometer evaluated the color in $\mathrm{CH}$ and $\mathrm{JB}$ samples through the $\mathrm{C}$ luminant integration sphere representing incandescent light, without methamerism calibrated with CIELAB color system. The $\mathrm{L}^{*} \mathrm{a}^{*}$ $b^{*}$ values were recorded, with four measurements in triplicate. The assay was carried out in fresh and cooked meat as control, raw charqui meat, cooked charqui meat, raw jerked meat and cooked jerked meat. The $a^{*} / b^{*}$ ratio was used to determine the metmyoglobin concentration (Wanous et al. 1989, Olivo et al., 2001).

\section{Statistical analysis}

Data were analyzed by ANOVA using the SAS (Statistical Analysis System) (1989). The main effects in analysis were treatments (control and cured samples) without interaction. Tukey's multiple range tests were used to determine significance difference among treatments $(\mathrm{p}<0.05)$.

\section{RESULTS AND DISCUSSION}

\section{Warmed-over flavor}

The exposition at relatively high temperature for a long period of time under the sunlight combined with high concentration of salt and the consequent final intermediate aw value promoted a considerable lipid oxidation in $\mathrm{CH}$ as shown in Fig. 1. The analyzed basic chemical composition was similar to the other charqui muscles as reported (Torres et al., 1989, Shimokomaki et al., 1998, Pinto et al., 2002). From the processing starting point up to the ready product and its storage it was observed an oxidation increase in a proportion of approx. 4 times only from $8^{\text {th }}$ day onward of processing. Moreover, in the first salting days, there were no relevant changes and that corresponded to the oxidation inducing phase in $\mathrm{CH}$ (Chen et al., 1984) and in fact, as reported previously, the oxidation occured initially in pigments and only observed in lipids at second stage of oxidation (Torres et al., 1988). TBARS was detected from the final stage of initiation to the propagation of lipid oxidation as described by Melton (1983). Thereafter, there was a steady increase of oxidation approximately 8 times during storage after $90^{\text {th }}$ day of processing. On the other hand, in cured JB the effect of nitrite antioxidant activities was noticeable. After processing, in desalted samples, TBARS measurement in both 
$\mathrm{CH}$ and JB samples revealed that there was approximately twice as much lipid oxidation in the nitrite-free charqui. Moreover, under conditions to promote WOF, TBARS values were $1.54 \mathrm{mg} / \mathrm{kg}$ for $\mathrm{CH}$ and $0.56 \mathrm{mg} / \mathrm{kg}$ for JB samples $(\mathrm{p}<0.05)$
(Table 1). The determined JB sodium nitrite average concentration was $13.90( \pm 2.01) \mathrm{ppm}$, which was obviously below the limit allowed by the legislation (Brasil, 2000).

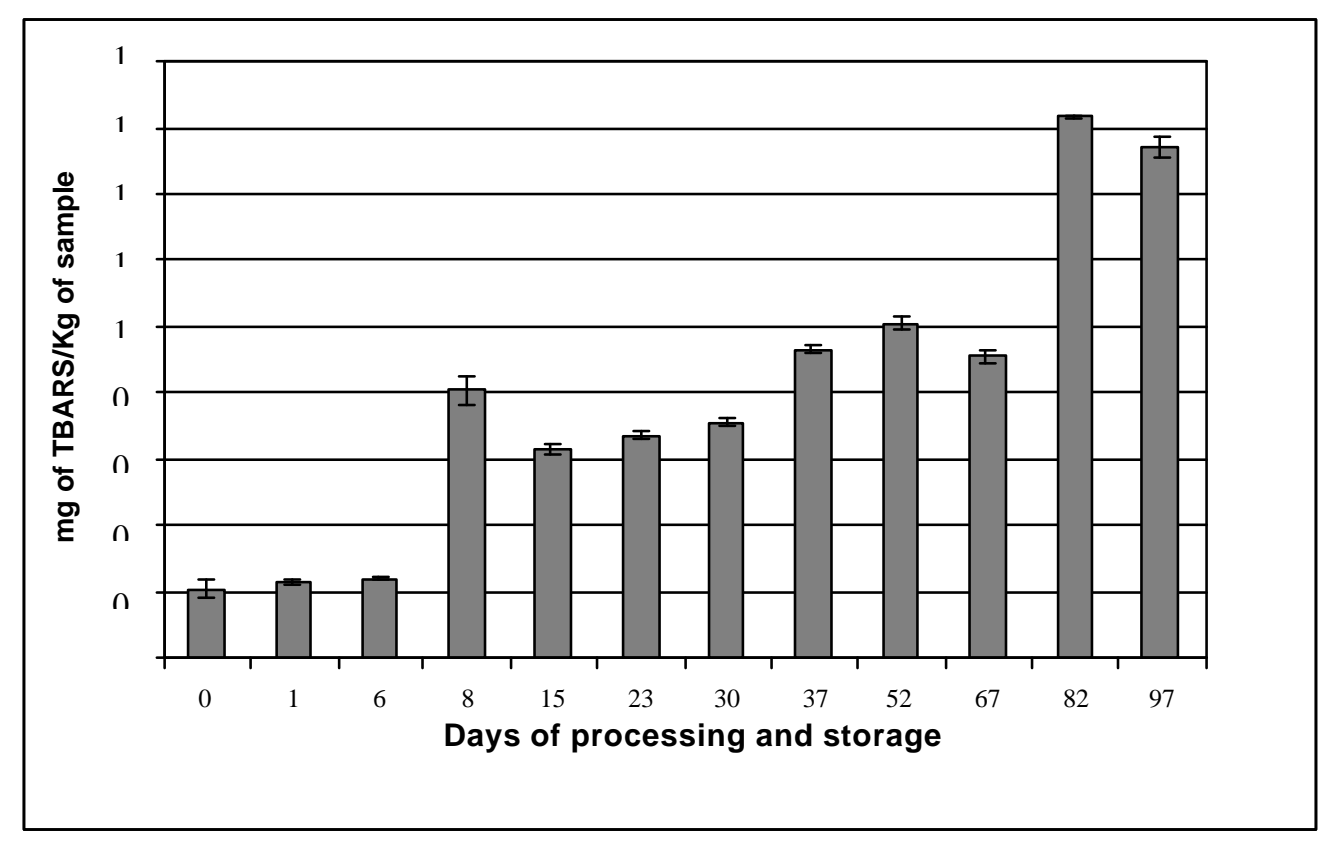

Figure 1 - Evolution of charqui meat rancidity during processing/storage.

Table 1 - Lipid oxidation and warmed over flavor determination in charqui meat and jerked beef from Vastus lateralis $m$. analyzed by Tarladgis et al., (1964) method ( $\mathrm{mg}$ of TBARS/kg of sample).

\begin{tabular}{ccc}
\hline Sample & Desalted * & Cooked (WOF)* \\
\hline & $0.72^{\mathrm{B} \mathrm{a}}$ & $1.54^{\mathrm{A} \mathrm{a}}$ \\
Charqui meat & $( \pm 0.07)$ & $( \pm 0.17)$ \\
& $0.39^{\mathrm{A} \mathrm{b}}$ & $0.56^{\mathrm{A} \mathrm{b}}$ \\
Jerked beef & $( \pm 0.08)$ & $( \pm 0.16)$ \\
\hline
\end{tabular}

* Mean $( \pm$ SD) $n=6$ triplicate samples
${ }^{a,-b}$ Within the same columns, means having different superscripts are significantly different $(p<0.05)$.
A, B Within the same row, having different superscripts are significantly different $(\mathrm{p}<0.05)$.

\section{Color}

The presence of $\mathrm{NaCl}$, sodium nitrite and the cooking procedures promoted changes in the color parameters as evaluated by CIELAB system. In Table 2 and Fig. 2, results are described from uncooked and cooked $\mathrm{CH}$ and JB samples in order to observe the WOF development. The $\mathrm{L}^{*}$ values were highest in fresh cooked meat followed by cooked $\mathrm{CH}$ and $\mathrm{JB}(\mathrm{p}<0.05)$ in comparison to the corresponded uncooked samples as shown in
Table 2. The higher values of $\mathrm{L}^{*}$ was caused by changes from $\mathrm{Fe}^{2+}$ to $\mathrm{Fe}^{3+}$ since uncooked samples were, red in color that changed to brownish as samples were cooked. However, the presence of nitrite kept the JB color as pink color after cooking maintaining iron at $\mathrm{Fe}^{2+}$. Also the $\mathrm{a}^{*}$ values were higher in JB and fresh samples and $b^{*}$ values increased depending on the oxidation state of $\mathrm{Fe}$ ions when raw and cooked $\mathrm{CH}$ and JB samples were compared to the original fresh samples. 
Table 2 - Charqui meat and Jerked beef from Vastus lateralis $m$. color evaluation by Hitachi spectrophotomer after different thermal treatments.

\begin{tabular}{|c|c|c|c|c|}
\hline & $\mathbf{L}^{*}$ & $\mathbf{a}^{*}$ & $\mathbf{b}^{*}$ & $\mathbf{a}^{* / \mathbf{b}^{*}}$ \\
\hline Fresh meat & $\begin{array}{l}42.44^{\mathrm{C}, \mathrm{D}} \\
( \pm 1.09)\end{array}$ & $\begin{array}{l}22.38^{\mathrm{A}} \\
( \pm 1.82)\end{array}$ & $\begin{array}{l}11.80^{\mathrm{A}} \\
( \pm 1.19)\end{array}$ & $\begin{array}{l}1.90^{\mathrm{B}} \\
( \pm 0.04)\end{array}$ \\
\hline Cooked meat & $\begin{array}{l}52.94^{\mathrm{A}} \\
( \pm 2.68)\end{array}$ & $\begin{array}{c}5.49^{\mathrm{C}} \\
( \pm 0.24)\end{array}$ & $\begin{array}{l}11.85^{\mathrm{A}} \\
( \pm 0.23)\end{array}$ & $\begin{array}{l}0.46^{\mathrm{D}} \\
( \pm 0.01)\end{array}$ \\
\hline Raw Charqui meat & $\begin{array}{l}39.97^{\mathrm{D}} \\
( \pm 1.53)\end{array}$ & $\begin{array}{l}3.54^{\mathrm{C}} \\
( \pm 0.31)\end{array}$ & $\begin{array}{l}3.69^{\mathrm{D}} \\
( \pm 0.32)\end{array}$ & $\begin{array}{c}0.96^{\mathrm{C}} \\
( \pm 0.06)\end{array}$ \\
\hline $\begin{array}{c}\text { Cooked charqui } \\
\text { meat }\end{array}$ & $\begin{array}{l}48.94^{\mathrm{B}} \\
( \pm 2.6)\end{array}$ & $\begin{array}{l}4.53^{C} \\
( \pm 0.36)\end{array}$ & $\begin{array}{l}9.64^{\mathrm{B}} \\
( \pm 0.81)\end{array}$ & $\begin{array}{l}0.47^{\mathrm{D}} \\
( \pm 0,04)\end{array}$ \\
\hline Raw Jerked Beef & $\begin{array}{l}40.33^{\mathrm{D}} \\
( \pm 1.09)\end{array}$ & $\begin{array}{l}13.56^{\mathrm{B}} \\
( \pm 1.73)\end{array}$ & $\begin{array}{l}4.99^{\mathrm{D}} \\
( \pm 1.17)\end{array}$ & $\begin{array}{l}2.72^{\mathrm{A}} \\
( \pm 0.37)\end{array}$ \\
\hline Cooked Jerked Beef & $\begin{array}{l}44.93^{\mathrm{C}} \\
( \pm 1.21)\end{array}$ & $\begin{array}{l}14.77^{\mathrm{B}} \\
( \pm 2.45)\end{array}$ & $\begin{array}{l}7.02^{\mathrm{C}} \\
( \pm 1.19)\end{array}$ & $\begin{array}{l}2.10^{\mathrm{B}} \\
( \pm 0.14)\end{array}$ \\
\hline
\end{tabular}

*Mean $( \pm$ SD) $n=6$ triplicate samples

A, B, C, D Within the same columns, means having different superscripts are significantly different $(\mathrm{p}<0.05)$.

The ratio $\mathrm{a}^{*} / \mathrm{b}^{*}$ showed that $\mathrm{CH}$ samples presented a brown color indicating the formation of metmyoglobin $\left(\mathrm{Fe}^{3+}\right)$ while JB samples presented a deep red color of nitrosylmyoglobin $\left(\mathrm{Fe}^{2+}\right)$. Under cooking, the ratio $\mathrm{a}^{*} / \mathrm{b}^{*}$ indicated the formation of denatured metmyoglobin in $\mathrm{CH}$ samples and nitrosylmyochromogen $\left(\mathrm{Fe}^{2+}\right)$ in JB samples rendering therefore color stabilization. Figure 2 showed the importance of color due to myoglobin molecule changes and their specific iron state during $\mathrm{CH}$ and JB processing. A close relationship between the actual iron state and rancidity in relation to the myoglobin oxidation was observed. $\mathrm{Fe}^{+3}$ was the iron state in $\mathrm{MMb}$ and denatured myoglobin forms rendered lipid oxidation in $\mathrm{CH}$ whereas for JB samples sodium nitrite kept this iron reduced at $\mathrm{Fe}^{2+}$ throughout processing/storage protecting further appearance of rancidity.

\section{Relationship between iron state and WOF in charqui meats}

During the harsh processing conditions, charqui meats proteins were denatured because of high salt concentration associated with a long period of dryness under the sunlight. Under these conditions, protein fractions no longer retained water and obviously cell membranes were disrupted as we demonstrated it ultrastructurally (Biscontini et al., 1996). Moreover, globin-bound haem fractions of haemoglobin and myoglobin lost their property to hold iron and there was a production of free iron, which unlikely would remain in its reduced state and is converted into oxidized form $\mathrm{Fe}^{+3}$. As a result, free radicals were formed and kept within the muscle being hexanal fraction the higher concentrated component as we demonstrated (Torres et al, 1989). Although not qualitatively analyzed in this work, it could be assumed than those components were still available since they were detected by TBARS in a re-heating experiment. In JB, the presence of sodium nitrite inhibited this lipid oxidation reaction and WOF formation became unpaired. Although the exact mechanism of action of its antioxidant role was not yet established, our results corroborated the assumption of Igene et al. (1985) that nitrite seemed to chelate free iron or stabilize cell membrane polyunsaturated lipids or finally to form a strong complex with haem pigments. 


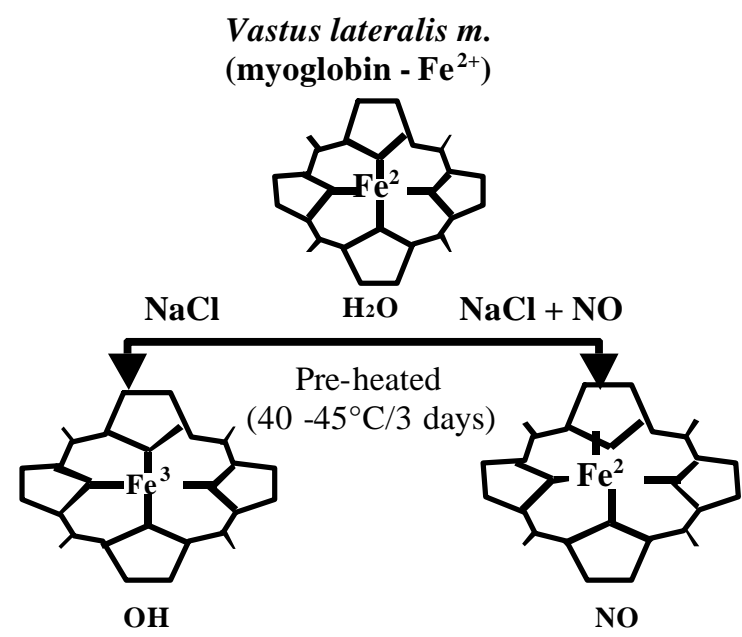

Charqui meat

Jerked beef meat

(Metmyoglobin $-\mathrm{Fe}^{3+}$ )

(Nitrosylmyoglobin $-\mathrm{Fe}^{2+}$ )
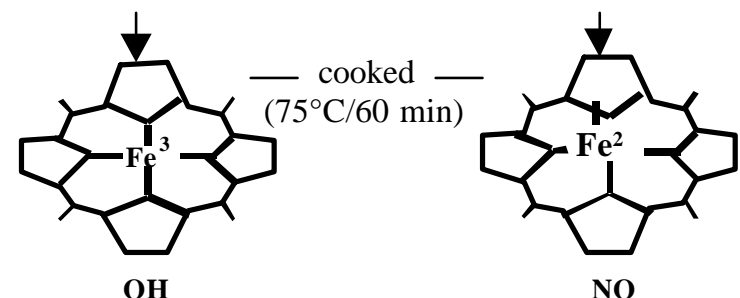

Cooked charqui meat (Denatured metmyoglobin $\left.\mathrm{Fe}^{3+}\right)$

Cooked Jerked beef (Nitrosylmyochromogen $\left.\mathrm{Fe}^{2+}\right)$

Figure 2 - Schematic representation of myoglobin and its iron state changes in charqui meat and jerked beef throughout processing and cooking.

\section{ACKNOWLEDGEMENTS}

Authors are thankful to FRIPAR Industrias e Comércio Ltda, Londrina, Brazil, for processing and donating charquis samples. EYY and CERG were under CAPES post graduation and $\mathrm{CNPq} / \mathrm{PIBIC}$ scholarships, respectively. MS is a CNPq Research Fellow. This work was partially supported by CNPq (Process \# 52 1047/96-0 (NV)

\section{RESUMO}

A associação entre a alta concentração do sal $(\mathrm{NaCl})$ e sais de cura $\left(\mathrm{NaNO}_{3}\right.$ e $\left.\mathrm{NaNO}_{2}\right)$ foi investigada quanto ao desenvolvimento do aroma de requentado (WOF) juntamente com as mudanças na coloração durante o processamento do charque e do Jerked beef. (JB). Em amostras armazenadas durante 30 dias, WOF ocorreu substancialmente em $\mathrm{CH}$ e nitrito de sódio foi capaz de inibir 40 a $45 \%(p<0,005)$ as amostras de JB. Os parâmetros de cor foram avaliados pelo sistema CIELAB. A razão $\mathrm{a}^{*} / \mathrm{b}^{*}$ mostrou que amostras de $\mathrm{CH}$ apresentaram-se com tonalidade amarronzada indicando a formação de metamioglobina $\left(\mathrm{Fe}^{3+}\right)$ enquanto que as de $\mathrm{JB}$ mostram uma coloração vermelha intensa indicando a formação da nitrosilmioglobina $\left(\mathrm{Fe}^{2+}\right)$. Durante o cozimento, a razão $\mathrm{a}^{*} / \mathrm{b}^{*}$ mostrou a presença da metamioglobina desnaturada $\left(\mathrm{Fe}^{3+}\right)$ no $\mathrm{CH}$ e a formação de nitrosilmiocromogenio $\left(\mathrm{Fe}^{2+}\right)$ em amostras de JB. O estado do íon ferro influenciou a cor do charque e de JB e aparentemente, o nitrito de sódio foi capaz de quelar íons $\mathrm{Fe} e$ conseqüentemente inibir o desenvolvimento do WOF. 


\section{REFERENCES}

Association of Official Analytical Chemistry (AOAC) (1995), Official methods of analysis of AOAC International.

Biscontini, T. M. B.; Shimokomaki, M.; Ferreira, S. O. and Zorn, T. M. T. (1996), An ultrastructural observation on charquis, salted and intermediate moisture meat products. Meat Sci., 43, 351-358.

Brasil. Ministério da Agricultura e Abastecimento. Divisão de Produtos de Origem Animal (2000), Circular $n^{\circ}$ 16/DICAR de 24/01/2000. Brasília.

Brasil. Ministério da Agricultura e Abastecimento. Departamento Nacional de Inspeção de Produtos de origem Animal (1967), Regulamento de inspeção industrial e sanitária de produtos de origem animal. Rio de Janeiro.

Igene, J. and Pearson, A. M. (1979), Role of phospholipids and triglycerides in warmed-over flavor development in meat model systems. J. Food Sci., 44, 1285-1290.

Igene, J. O.; Yamauchi, K.; Pearson, A. M. and Gray, J. I. (1985) Mechanisms by which nitrite inhibits the development of warmed-over flavor (WOF) in cured meat. Food Chem., 18, 1-18.

Leistner, L. (1987) Shelf stable product and intermediate moisture foods based on meat. In Rockland L and Beuchat L B (eds.). Water activity theory and application to food, New York : Marcel Dekker Inc. pp. 295-328.

Melton, S. L. (1983), Methodology for following lipid oxidation in muscle foods. Food Techonol., 37, 105-111.

Olivo, R.; Soares, A. L.; Ida, E. I. and Shimokomaki, M. (2001), Dietary Vitamin E Inhibits Poultry PSE and Improves Meat Functional Properties. J. Food Biochem., 25, 271-283.

Pegg, R. B. and Shahidi, F. (1997).Unraveling the Chemical Identity of Meat Pigments. Critical Reviews in Food Science. Nutrition., Boca Raton, 37, 561-589.

Pinto, M. F.; Ponsano, E G. H.; Franco, B. D. G. M. and Shimokomaki, M. (2002), Charqui Meats as Fermented Meat Products: Role of Bacteria for Some Sensorial Properties Development Meat Sci., 61, 187-91.

Shahidi, F. (1994), Assessment of lipid oxidation and off-flavor development in meat and meat products. In: (ed.), Flavor of meat and meat products. London. Academic of Professional. pp. 247-266.

Shimokomaki, M.; Franco, B. D. G. M. and Biscontini, T. M. B. et al. (1998), Charqui meats are hurdle technology meat products. Food Reviews International, 14, 339-349.

Statistical Analysis System. (1989), SAS user's guide for personal computers. $5^{\text {th }} \mathrm{ed}$. The Institute : N $\mathrm{C}$ : Cary.
Tarladgis, B. G.; Pearson, A. M. and Dugan, R. (1964), Chemistry of the 2-thiobarbituric acid test for determination of oxidative rancidity in foods. IIFormation of the TBA-malonaldehyde complex without acid-heat treatment. J.Food Sc. Agric., 5, 602-604.

Tims, M. J. and Watts, B. M. (1958), Protection of cooked meats with phosphates. Food Technol. 12, 240-243.

Torres, E.; Pearson, A. M.; Gray, J. I. and Shimokomaki, M. (1988), Effect of salt on oxidative changes in pre- and post-rigor ground beef. Meat Sc., 23, 151-163.

Torres E.; Pearson, A .M.; Gray, J.; Ku P. K and Shimokomaki, M. (1989) Lipid oxidation in charqui (salted and dried beef), Food Chem., 32, 257-268.

Torres E. A. F. S.; Shimokomaki, M.; Franco, B. D. G. M.; Landgraf, M.; Carvalho Jr., B. C C. and Santos, J. C. (1994), Parameters determining the quality of charqui, an intermediate moisture meat product. Meat Sci., 38, 229-234.

Younathan, M. T. and Watts, B. M. (1959), Relationships of meat pigments to lipid oxidation. Food Research, 24, 728-734.

Younathan, M. T. (1985), Causes and prevention of Warmed over Flavor. Proceeding Annual Reciprocal Meat Conference, 38, 74-80.

Wanous, M. P.; Olson, D. G. and Kraft, A. A. (1989), Pallet location and freezing rate effects on the oxidation of lipids and myoglobin in commercial fresh pork sausage. J. Food Sci., 54, 549-552.

Received: March 11, 2002 Revised: August 29, 2002; Accepted: March 20, 2003. 